\title{
Intensitas Penggunaan Media Sosial ditinjau dari Kebutuhan Afiliasi Pada Siswa-Siswi Kelas XI SMA Panca Budi Medan
}

\section{Intensity Of Social Media Usage Viewed From Affiliation Needs On Students Of Class XI at Sma Panca Budi Medan}

\author{
Ryzka Rosta Octavia(1)*,Josep Hutty Pardamean Malau(2), Diny Atrizka(3) \& Dearni \\ Cintya Dewi(4) \\ Fakultas Psikologi, Universitas Prima Indonesia, Indonesia
}

Disubmit: 02 September 2020; Diproses: 02 September 2020; Diaccept: 14 November 2020; Dipublish: 01 Desember 2020 *Corresponding author: E-mail: ryzkarostaoct@gmail.com

\begin{abstract}
Abstrak
Penelitian ini bertujuan untuk mengetahui hubungan antara kebutuhan afiliasi dengan intensitas penggunaan media sosial. Subjek yang digunakan dalam penelitian ini adalah siswa dan siswi di SMA PAnca Budi Medan sebanyak 152 orang sebanyak 152 orang yang dipilih dengan metode purposive sampling. Data diperoleh dari skala untuk mengukur kebutuhan afiliasi dan intensitas penggunaan media sosial. Perhitungan dilakukan dengan melakukan uji analisis (uji asumsi) yang terdiri dari uji normalitas sebaran dan uji linearitas hubungan. Analisis data yang digunakan adalah menggunakan korelasi Product Moment melalui bantuan SPSS 18 for Windows. Hasil analisis data menunjukkan koefisien korelasi sebesar 0,679 dan nilai signifikansi sebesar 0,000 ( $p<0,05)$. Ini menunjukkan ada hubungan positif antara kebutuhan afiliasi dengan intensitas penggunaan media sosial. Hasil penelitian ini menunjukkan bahwa sumbangan yang diberikan variable kebutuhan afiliasi terhadap intensitas penggunaan media sosial adalah sebesar 46,1\%, selebihnya 53,3\% dipengaruhi oleh faktor lain yang tidak diteliti. Berdasarkan hasil penelitian ini dapat ditarik kesimpulan bahwa hipotesis penelitian diterima, yaitu ada hubungan positif antara kebutuhan afiliasi dengan intensitas penggunaan media sosial.
\end{abstract}

Kata Kunci: Intensitas Penggunaan Sosial Media; Kebutuhan Afiliasi; Siswa

\begin{abstract}
This study aims to determine the correlation between affiliation needs and the intensity of social media usage. Subjects used in this study were Senior High School students at Panca Budi Medan as many as 152 students selected by a purposive sampling method. Data were obtained by affiliation needs scale and the intensity of social media usage's scale. The calculation was performed by conducting the analysis test (assumption test), which consists of a normality test for distribution and linearity test for relationships. The data analysis used is Product Moment Correlation with SPSS 18 for Windows. The results of data analysis showed that the correlation coefficient was 0,679 with $p=0.000(p<0.05)$. It meant that there was a positive relationship between affiliation needs and the intensity of social media usage. These results indicated that the contribution given by the variable of affiliation needs to the intensity of social media usage is at 46,1\%, while the remaining 53,3\% influenced by other factors which are not examined. Based on the results, it can be concluded that the research hypothesis was accepted, and there was a positive correlation between affiliation needs and the intensity of social media usage.
\end{abstract}

Keywords: Affiliation Needs; Intensity of Social Media; Student

Rekomendasi mensitasi :

Octavia, R.R., Malau, J.H.P., Atrizka, D., \& Dewi, D.C., 2020. Intensitas Penggunaan Media Sosial ditinjau dari Kebutuhan Afiliasi Pada Siswa-Siswi Kelas XI SMA Panca Budi Medan. Jurnal Penelitian Pendidikan, Psikologi dan Kesehatan (J-P3K), 1(3): 182-189. 


\section{PENDAHULUAN}

Pada hakikatnya di dalam diri manusia terdapat hasrat untuk berkomunikasi, bergaul, dan bekerja sama dengan orang lain. Berinteraksi dengan orang lain merupakan kebutuhan mendasar dalam diri manusia. Salah satu bentuk interaksi antara satu manusia dengan manusia yang lain adalah dengan komunikasi. komunikasi merupakan sesuatu transaksi, proses simbolik yang menghendaki orang-orang mengendalikan lingkungannya dengan (1) membangun ikatan antara sesama manusia; (2) melalui pertukaran informasi; (3) untuk memantapkan perilaku serta tingkah laku orang lain; dan (4) berupaya mengganti perilaku serta tingkah laku itu (Nofrion, 2016).

Komunikasi adalah proses penyampaian pesan dari komunikator kepada komunikan melalui media tertentu untuk menghasilkan efek atau tujuan dengan mengharapkan feedback atau umpan balik (Daryanto, 2018). Menurut Ginting (2017) menyatakan bahwa komunikasi adalah proses dua arah untuk mencapai satu pengertian atau pemahaman, dimana para partisipan tidak hanya bertukar informasi, berita, gagasan, dan perasaan, tetapi juga menciptakan dan berbagi makna.

Di era globalisasi saat ini, media sosial menempati peran penting untuk berinteraksi antara satu dengan yang lainnya. Media sosial adalah kelompok dari aplikasi berbasiskan internet yang dibangun atas dasar ideologi dan teknologi web versi 2.0 yang memungkinkan terciptanya website yang interaktif (Sulianta, 2015). Media sosial adalah media online yang memungkinkan bagi pengguna untuk berpartisipasi, berbagi, dan menciptakan isi (Herlanti, 2014). Lebih lanjut, Bosman dan Zagenczyk (Herlanti, 2014) menyebutkan bahwa media sosial memiliki sifat berhubungan, berbagi, dan berkolaborasi (connecting, sharing, and collaborating).

Berdasarkan data statistik penggunaan internet di Indonesia, ratarata penduduk Indonesia menghabiskan waktu mengakses data selama 5,5 jam per hari. Sementara penggunaan smartphone atau telepon genggam sekitar 2,5 jam per hari (Santosa, 2015).

Penggunaan media sosial yang berlebihan ternyata dapat menimbulkan dampak serius, seperti yang terjadi pada seorang remaja asal Perth, Australia Barat, telah memiliki akun instagram sejak berusia 13 tahun. Ia merasakan tekanan untuk mendokumentasikan setiap aktivitas yang dilakukannya (Liputan6, 2017). Kasus serupa ternyata juga pernah terjadi di Indonesia, seperti yang terjadi pada 2 remaja di Bondowoso, Jawa Timur. Remaja A (17) dan H (15) telah berada di Poli Jiwa Rumah Sakit Umum Daerah Dokter Koesnadi, Bondowoso, Jawa Timur. Mereka dirawat disebabkan kecanduan smartphone ponsel (Liputan6, 2018).

Berdasarkan hasil wawancara dan observasi di SMA Panca Budi Medan, banyak siswa yang mengatakan bahwa lebih sering bermain media sosial meski hanya mengecek instagram atau line mereka. Hampir 15 menit sekali mereka mengecek ponsel mereka untuk mengetahui kabar di media sosial mereka. Beberapa siswa juga mengatakan akan melihat media sosial mereka meskipun 
sambil mengendarai kendaraan. Akibatnya banyak siswa mengaku tidak belajar setelah pulang sekolah karena sibuk bermain media sosial, ada juga yang sibuk bermain media sosial sehingga tidak peduli lingkungan disekitarnya.

Menurut Azwar (2000) intensitas merupakan suatu kekuatan atau kedalaman sikap terhadap sesuatu. Menurut Ajzen (1991) intensitas merupakan suatu usaha seseorang atau individu dalam melakukan tindakan tertentu. Intensitas penggunaan media sosial adalah ukuran kuantitatif yang mengacu kepada keinginan mengakses atau menggunakan media sosial. Menurut Maslow (Hasibuan, 2005) kebutuhan afiliasi adalah kebutuhan sosial, dicintai dan mencintai serta diterima dalam pergaulan kelompok dan lingkungannya. Santoso (2011) mengemukakan bahwa kebutuhan untuk melakukan afiliasi merupakan kebutuhan yang pemenuhannya memerlukan hubungan yang hangat dan akrab dengan orang lain.

Berdasarkan uraian di atas terlihat jika remaja memiliki kebutuhan afiliasi yang tinggi dapat mempengaruhi tingkat intensitas dalam penggunaan media sosial, maka peneliti tertarik untuk meneliti tentang "intensitas penggunaan media sosial ditinjau dari kebutuhan afiliasi siswa-siswi kelas XI SMA Panca Budi Medan. Maka tujuan dari penelitian ini untuk mencari hubungan antara kebutuhan afiliasi dengan intensitas penggunaan media sosial di SMA Panca Budi Medan.

Berdasarkan penjelasan yang telah dikemukakan di atas, maka dapat diajukan hipotesis sebagai berikut ada hubungan positif antara kebutuhan afiliasi dengan intensitas penggunaan media sosial. Diasumsikan bahwa semakin tinggi kebutuhan afiliasi seseorang, maka intensitas penggunaan media sosial semakin tinggi, begitu pula sebaliknya semakin rendah kebutuhan afiliasi seseorang, maka intensitas penggunaan media sosial akan semakin rendah.

\section{METODE PENELITIAN}

Metode penelitian yang digunakan adalah kuantitatif. Variabel terikat yaitu intensitas penggunaan media sosial. Variabel bebasnya adalah kebutuhan afiliasi. Intensitas penggunaan media sosial adalah ukuran kuantitatif yang mengacu kepada keinginan mengakses atau menggunakan media sosial. Kebutuhan afiliasi yang dimaksudkan dalam penelitian ini adalah sebuah kebutuhan untuk menjalin hubungan yang akrab dan hangat dengan orang lain orang. Menurut Sugiyono (2016) populasi adalah wilayah generalisasi yang terdiri atas obyek/subyek yang mempunyai kualitas dan karakteristik tertentu yang ditetapkan oleh peneliti untuk dipelajari dan kemudian ditarik kesimpulannya. Populasi dalam penelitian ini merupakan seluruh siswa SMA Panca Budi Medan yang berjumlah 267 orang.

Sampel merupakan bagian dari sebuah populasi yang dianggap mewakili sebagian dari populasi itu (Hasan, 2013). Jumlah sampel diambil menurut tabel penentu jumlah sampel dari tabel penentu jumlah sampel dari populasi spesifik yang dikembangkan oleh Isaac dan Michael (Sugiyono, 2016). Dalam hal ini, peneliti menentukan jumlah sampel dengan 
menggunakan taraf kesalahan 5\%. Jumlah populasi SMA Panca Budi Medan sebanyak 267 orang, untuk taraf kesalahan 5\% maka jumlah sampelnya adalah 152 orang.

Metode pengumpulan data adalah teknik atau cara yang dilakukan untuk memperoleh informasi yang dibutuhkan dalam rangka mencapai tujuan penelitian. Skala menggambarkan prosedur menentukan angka untuk berbagai tingkat pendapat, sikap dan konsep lainnya (Duli, 2019). Metode yang digunakan dalam pengumpulan data yaitu metode pembagian skala untuk mengukur intensitas penggunaan media sosial dan kebutuhan afiliasi.

Skala intensitas penggunaan media sosial yang digunakan pada penelitian ini disusun berdasarkan aspek intensitas penggunaan media sosial yang dikemukakan oleh Ajzen (1991) yang mengelompokan intensitas penggunaan media sosial menjadi empat aspek, yaitu: aspek perhatian, aspek penghayatan, aspek durasi, dan aspek frekuensi.

Skala kebutuhan afiliasi yang digunakan dalam penelitian ini menggunakan aspek Hill (Baron \& Byrne, 2003) diantaranya, yaitu; kebutuhan atas stimulasi positif (need of positive stimulation), kebutuhan akan dukungan sosial (need of social support), kebutuhan akan perhatian (need of attention), dan kebutuhan akan perbandingan sosial (need of social comparison).

Jenis validitas yang dipakai dalam penelitian ini adalah validitas isi. Validitas isi merupakan validitas yang diestimasi lewat pengujian terhadap isi tes dengan analisis rasional atau lewat expert judgement (Azwar, 2016). Pengertian reliabilitas mengacu pada keandalan atau konsistensi hasil pengukuran, yang mengandung makna seberapa tinggi kecermatan pengukuran. Reliabilitas dinyatakan dalam koefisien dengan angka antara 0 hingga 1,00. Semakin tinggi koefisiennya, semakin mendekati 1,00 berarti reliabilitas alat ukur semakin tinggi. Sebaliknya reliabilitas alat ukur yang rendah ditandai oleh koefisien reliabilitas yang mendekati angka 0 (Azwar, 2011).

Penelitian ini merupakan penelitian kuantitatif, yaitu kegiatan pengumpulan, pengolahan, analisis, dan penyajian data yang dilakukan secara sistematis dan objektif untuk memecahkan suatu persoalan atau menguji suatu hipotesis untuk mengembangkan prinsip-prinsip umum.

\section{HASIL DAN PEMBAHASAN}

Berdasarkan tujuan penelitian maka dilakukan uji Pearson Correlation. Menurut hasil analisis korelasi antara kebutuhan afiliasi dengan intensitas penggunaan media sosial, diperoleh koefisien korelasi product moment sebesar $r=0,679$ dengan sig sebesar 0,000 (p < $0,05)$. Hal ini menunjukkan bahwa adanya korelasi positif antara kebutuhan afiliasi dengan intensitas penggunaan media sosial sehingga dikategorikan hubungan yang sangat kuat (Priyatno, 2010).

Dari hasil perhitungan tersebut, maka hipotesis yang diajukan dalam penelitian ini menunjukkan ada hubungan positif antara kebutuhan afiliasi dengan intensitas penggunaan media sosial pada siswa-siswi diterima, dan dapat dinyatakan bahwa ada hubungan positif 
antara kebutuhan afiliasi dengan intensitas penggunaan media sosial.

Berdasarkan hasil penelitian dan wawancara singkat terhadap siswa dan siswi di SMA Panca Budi Medan, banyak siswa yang mengatakan bahwa lebih sering bermain media sosial meski hanya mengecek instagram atau line mereka. Beberapa siswa juga mengatakan jarang melepaskan smartphone atau tidak bisa pergi atau berada jauh dari smartphone. Mereka selalu mengecek ponsel mereka untuk mengetahui kabar di media sosial mereka. Beberapa siswa juga mengatakan akan melihat media sosial mereka meskipun sambil mengendarai kendaraan.

Akibatnya banyak siswa mengaku tidak belajar setelah pulang sekolah karena sibuk bermain media sosial, ada juga yang sibuk bermain media sosial sehingga tidak peduli lingkungan disekitarnya. Beberapa siswa juga mengatakan bahwa media sosial cukup membantu mereka dalam kehidupan sehari-hari, seperti melihat berita terkini lebih mudah dengan media sosial. Melalui media sosial siswa dan siswi menyatakan dapat mengetahui berbagai kejadian yang terjadi khususnya di Medan melalui akun instagram Medan talk. Siswa dan siswi juga mengatakan bahwa karena kemudahan menggunakan media sosial yang dapat dilakukan dimana saja mereka mampu memanfaatkan media sosial sebagai sumber informasi yang mendukung tugas sekolah.

Hasil analisis untuk intensitas penggunaan sosial media diperoleh mean empirik < mean hipotetik yaitu 116.51 < 90 maka dapat disimpulkan bahwa intensitas penggunaan media sosial pada subjek penelitian lebih tinggi daripada populasi pada umumnya.

Tabel 1. Kategorisasi Intensitas Penggunaan Media Sosial

\begin{tabular}{|c|c|c|c|c|}
\hline Variabel & $\begin{array}{l}\text { Rentang } \\
\text { Nilai }\end{array}$ & Kategori & $\begin{array}{l}\text { Jumlah } \\
\text { (n) }\end{array}$ & $\begin{array}{l}\text { Persen } \\
\text { tase }\end{array}$ \\
\hline Inten & $x<72$ & Rendah & 0 & $0 \%$ \\
\hline $\begin{array}{l}\text { sitas } \\
\text { Media }\end{array}$ & $\begin{array}{l}72 \leq \quad x \\
<108\end{array}$ & Sedang & 23 & $14,6 \%$ \\
\hline Sosial & $x \geq 108$ & Tinggi & 129 & $85,3 \%$ \\
\hline Jumlah & & & 152 & $100 \%$ \\
\hline
\end{tabular}

Berdasarkan kategori pada Tabel 1. maka dapat dilihat bahwa tidak terdapat subjek (0 \%) yang memiliki intensitas media sosial rendah, terdapat 23 subjek $(14,6 \%)$ yang memiliki intensitas media sosial sedang, dan terdapat 129 subjek $(85,3 \%)$ yang memiliki intensitas penggunaan media sosial tinggi. Berdasarkan penjelasan di atas maka dapat ditarik disimpulkan bahwa rata-rata subjek penelitian memiliki intensitas penggunaan media sosial yang tinggi.

Hasil analisis untuk kebutuhan afiliasi diperoleh mean empirik < mean hipotetik yaitu 199.18>75 maka dapat disimpulkan bahwa kebutuhan afiliasi pada subjek penelitian lebih tinggi daripada populasi pada umumnya.

Tabel 2. Kategorisasi Data Kebutuhan Afiliasi

\begin{tabular}{|c|c|c|c|c|}
\hline Variabel & $\begin{array}{l}\text { Rentang } \\
\text { Nilai }\end{array}$ & $\begin{array}{l}\text { Katego } \\
\text { ri }\end{array}$ & $\begin{array}{l}\text { Jum } \\
\text { lah }\end{array}$ & $\begin{array}{l}\text { Persent } \\
\text { ase }\end{array}$ \\
\hline $\begin{array}{l}\text { Kebutuh } \\
\text { an } \\
\text { afiliasi }\end{array}$ & $\begin{array}{l}x<60 \\
60 \leq x \\
<90 \\
x \geq 90\end{array}$ & $\begin{array}{l}\text { Rendah } \\
\text { Sedang } \\
\text { Tinggi }\end{array}$ & $\begin{array}{l}0 \\
54 \\
98\end{array}$ & $\begin{array}{l}0 \% \\
37,3 \% \\
62,37 \%\end{array}$ \\
\hline Jumlah & & & 152 & $100 \%$ \\
\hline
\end{tabular}

Berdasarkan kategori pada Tabel 2 . maka dapat dilihat bahwa tidak terdapat 
subjek (0 \%) yang memiliki kebutuhan afiliasi rendah, terdapat 54 subjek $(37,3$ $\%)$ yang memiliki kebutuhan afiliasi sedang, dan terdapat 98 subjek $(62,7 \%)$ yang memiliki kebutuhan afiliasi tinggi. Berdasarkan penjelasan di atas maka dapat disimpulkan bahwa rata-rata subjek penelitian memiliki kebutuhan afiliasi tinggi.

Hasil penelitian pada 152 murid di SMA Panca Budi Medan yang menjadi subjek penelitian, diperoleh hasil bahwa ada hubungan antara kebutuhan afiliasi dengan intensitas penggunaan media sosial dengan koefisien korelasi Product Moment sebesar $\mathrm{r}=0,679$ dan nilai $\mathrm{p}=$ 0,000 artinya semakin tinggi kebutuhan afiliasi maka semakin tinggi intensitas penggunaan media sosial, dan sebaliknya semakin rendah kebutuhan afiliasi maka semakin rendah intensitas penggunaan media sosial.

Berdasarkan tujuan penelitian, maka dilakukan uji Pearson correlation. Hasil uji korelasi dapat dilihat pada Tabel 3. di bawah ini.

Tabel 3. Korelasi Antara Kebutuhan Afiliasi dengan Intensitas Media Sosial .

\begin{tabular}{lcl}
\hline Analisis & $\begin{array}{l}\text { Pearson } \\
\text { Correlation }\end{array}$ & $\begin{array}{l}\text { Signifikaan } \\
(\mathrm{p})\end{array}$ \\
\hline Korelasi & 0,0679 & 0,000 \\
\hline
\end{tabular}

Dari hasil perhitungan tersebut, maka hipotesis yang diajukan dalam penelitian ini menunjukkan ada hubungan positif antara kebutuhan afiliasi dengan intensitas penggunaan media sosial pada siswa-siswi diterima, dan dapat dinyatakan bahwa ada hubungan positif antara kebutuhan afiliasi dengan intensitas penggunaan media sosial.
Tabel 4. Sumbangan Efektif

\begin{tabular}{lllll} 
Model & $r$ & rsquare & $\begin{array}{l}\text { adjust } \\
r \\
\text { square }\end{array}$ & $\begin{array}{l}\text { std. error } \\
\text { of } \\
\text { estimate }\end{array}$ \\
\hline 1 & .679 & .461 & .458 & 5,338 \\
\hline
\end{tabular}

Berdasarkan Tabel 4. di atas, dapat disimpulkan dalam penelitian ini diperoleh koefisien determinasi $\left(\mathrm{r}^{2}\right)$ sebesar 0,461. Berdasarkan hasil tersebut, dapat disimpulkan bahwa sumbangan 46,1 persen kebutuhan afiliasi mempengaruhi intensitas penggunaan media sosial dan selebihnya 53,3 persen dipengaruhi oleh faktor lain, seperti kepuasan kerja, komitmen organisasi, kecerdasan emosi, budaya organisasi, kepemimpinan, kepribadian, motivasi kerja dan kualitas kehidupan kerja.

Penelitian ini kemudian diperkuat oleh penelitian sebelumnya yang dilakukan oleh Putra dan Marhaeni (2015), terhadap 451 orang remaja akhir yang berdomisili di Provinsi Bali. Hasil penelitiannya menyatakan bahwa adanya hubungan yang signifikan antara kebutuhan afiliasi dengan intensitas penggunaan jejaring sosial twitter pada remaja akhir di Bali $(r=0,342$ dan $\mathrm{p}=$ 0,000 ) yang artinya semakin tinggi kebutuhan afiliasi maka semakin tinggi pula intensitas penggunaan media sosial, begitu pula sebaliknya.

Hasil penelitian ini juga senada dengan penelitian yang dilakukan oleh beberapa peneliti seperti penelitian yang dilakukan oleh Rinjani dan Firmanto (2013), terhadap 50 orang remaja pengguna facebook yang dimana akun facebook mereka terhubung dengan akun facebook peneliti yang menunjukkan 
bahwa adanya korelasi yang positif dan signifikan antara kebutuhan afiliasi dengan intensitas mengakses facebook ( $\mathrm{r}$ $=0,675$ dan $p<0,05)$. Artinya bahwa semakin tinggi kebutuhan afiliasi maka intensitas mengakses facebook semakin tinggi juga, sebaliknya semakin rendah kebutuhan afiliasi maka intensitas mengakses facebook semakin rendah.

\section{SIMPULAN}

Hasil uji Pearson Correlation pada hipotesis membuktikan bahwa ada hubungan positif antara intensitas penggunaan media sosial dan kebutuhan afiliasi dengan nilai koefisien korelasi product moment $r=0,679$ dan $\mathrm{p}=0,000(\mathrm{p}$ $<0,005)$, dan nilai $r$ square $\left(r^{2}\right)=0,461$, artinya semakin tinggi kebutuhan afiliasi maka semakin tinggi intensitas penggunaan media sosial, dan sebaliknya semakin rendah kebutuhan afiliasi maka semakin rendah intensitas penggunaan media sosial.

Hasil penelitian ini membuktikan bahwa sumbangan efektif yang diberikan variabel kebutuhan afiliasi terhadap variabel intensitas penggunaan media sosial adalah sebesar 46,1\%, selebihnya $53,3 \%$ dipengaruhi oleh faktor lain yang tidak diteliti, seperti aktualisasi diri, relatedness, depresi, dan perilaku konsumtif.

\section{UCAPAN TERIMAKASIH}

Kami mengucapkan terimakasih pada semua pihak yang sudah bekerjasama dan membantu proses penelitian, guru-guru serta Kepala Sekolah SMA Panca Budi Medan yang telah membantu kami dan memberikan kami penelitian di sekolah SMA Panca Budi Medan dan telah memberi informasi dan motivasi serta bimbingan selama melaksanakan Penelitian di SMA Panca Budi Medan, dan seluruh siswa SMA Panca Budi Medan yang mengikuti kegiatan penelitian, yang banyak membantu kami dalam pelaksanaan proses penelitian.

\section{DAFTAR PUSTAKA}

Ajzen, I. (1991). Attitudes, Personality, E Behavior. New York: Open University Press.

Azwar, S. (2016). Metode Penelitian. Yogyakarta: Pustaka Belajar.

Azwar, S. (2011). Reliabilitas dan Validitas. Yogyakarta: Pustaka Belajar.

Azwar, S. (2000). Sikap Manusia, Teori dan Pengakuannya. Yogyakarta: Pustaka Pelajar Offset.

Baron, R. A., \& Byrne, D. (2003). Psikologi Sosial Jilid 1. Jakarta: Erlangga.

Daryanto. (2018). Teori Komunikasi. Malang: Gunung Samudera.

Duli, N. (2019). Metodologi Penelitian Kuantitatif: Beberapa Konsep Dasar Untuk Penulisan Skripsi \& Analisis Data Dengan SPSS. Yogyakarta: Penerbit Deepublish.

Ginting, D. (2017). Komunikasi Cerdas: Panduan Berkomunikasi di Dunia Kerja. Jakarta: PT Elex Media Komputindo.

Hasan. (2013). Marketing dan Kasus-kasus Pilihan. Yogyakarta: Center of Academic Publishing.

Hasibuan. (2005). Organisasi dan Motivasi Dasar Peningkatan Produktivitas. Jakarta: Bumi Aksara.

Herlanti. (2014). Program Studi Pendidikan Ilmu Pengetahuan Alam. Dipetik September 22, 2018, dari BlogQuest: https://books.google.co.id/books?id=FGQZ DQAAQBAJ\&amp;printsec $=$ frontcover\&amp ;dq=herlanti+2014\&amp;hl=id\&amp;sa=X\&a mp;ved=oahUKEwiqz4qqsYbiAhULOSsKH QgiCcQQ6AEILjAB\#v=onepage\&amp; $\mathrm{q}=$ her lanti\%202014\&amp;f=false

Liputan6. (2018). Kecanduan Smartphone, Begini Kondisi 2 Remaja di RS Jiwa Bondowoso. Dipetik Juni 22, 2018, dari Liputan6.com: http://m.liputan6.com/news/read/3230544/ kecanduan-smartphone-begini-kondisi-2remaja-di-rs-jiwa-bondowoso 
Liputan6. (2017). Pengakuan Remaja Australia Yang Kecanduan Instagram. Dipetik Juni 22, 2018, dari Liputan6.com: http://m.liputan6.com/global/read/3122852/ pengakuan-remaja-australia-yangkecanduan-instagram\#

Nofrion. (2016). Komunikasi Pendidikan: Penerapan, Teori dan Konsep Komunikasi. Jakarta: Kencana.

Priyatno, D. (2010). 5 Jam Belajar Olah Data dengan SPSS 19. Yogyakarta: Andi.

Putra, I. P., \& Marhaeni, A. (2015). Hubungan Kebutuhan Afiliasi Dengan Intensitas Penggunaan Jejaring Sosial Twitter Pada Remaja Akhir. Jurnal Psikologi Udayana , 48-58.

Rinjani, H., \& Firmanto, A. (2013). Kebutuhan Afiliasi Dengan Intensitas Mengakses Facebook Pada Remaja. Jurnal Ilmiah Psikologi Terapan , 76-85.

Santosa, E. T. (2015). Raising Children in Digital Era. Jakarta: PT Elex Media Komputindo.

Santoso, A., P, M., \& Roestamadji. (2011). Motif Afiliasi Pengguna Aktif Facebook. Jurnal Fakultas Psikologi Universitas Semarang .

Sugiyono. (2016). Metode Penelitian Kuantitatif Kualitatif dan Kombinasi (Mixed Methods). Bandung: Alfabeta.

Sulianta, F. (2015). Keajaiban Sosial Media. Jakarta: PT Elex Media Komputindo. 